\title{
A Pathogenicity Gene Isolated from the pPATH Plasmid of Erwinia herbicola pv. gypsophilae Determines Host Specificity
}

\author{
Lea Valinsky, ${ }^{1,2}$ Shulamit Manulis, ${ }^{1}$ Roni Nizan, ${ }^{2}$ David Ezra, ${ }^{1,2}$ and Isaac Barash ${ }^{2}$ \\ ${ }^{1}$ Department of Plant Pathology, ARO, The Volcani Center, P.O.B. 6, Bet Dagan 50250; and 'Department of \\ Plant Sciences, Tel-Aviv University, Tel-Aviv 69978, Israel \\ Accepted 15 April 1998.
}

The host range of the gall-forming bacterium Erwinia herbicola pv. gypsophilae (Ehg) is restricted to the gypsophila plant whereas $E$. herbicola pv. betae (Ehb) incites galls on beet as well as gypsophila. The pathogenicity of $\mathrm{Ehg}$ and Ehb was previously shown to be dependent on a plasmid (pPATH). Transposon mutagenesis was used to generate mutants on the cosmid pLA150 of the pPATH from Ehg824-1. A cluster of nonpathogenic mutations flanked by two IS1327 elements was identified on a 3.2-kb NdeI DNA fragment. All mutants were restored to pathogenicity by complementation in trans with the wild-type Ehg DNA. DNA sequence analysis of the 3.2-kb NdeI fragment revealed a single open reading frame (ORF) of $2 \mathrm{~kb}$ as well as a potential ribosome binding site and a putative $h r p$ box upstream to the ORF. The ORF had no significant homology to known genes. Southern analysis also revealed the presence of DNA sequences that hybridized to the ORF in the beet pathovar Ehb4188. This gene was isolated and sequenced. Marker exchange mutants generated in the ORF of $E h b$ eliminated the pathogenicity of $E h b$ on gypsophila but fully retained its pathogenicity on beet. Since the putative gene appeared to encode a host-specific virulence factor for gypsophila it was designated as $h s v G$.

Additional keywords: type III secretion system.

Erwinia herbicola is widespread in nature as an epiphyte on many plants (Starr 1981). However, some strains have evolved into plant pathogens that incite gall formation in gypsophila (Gypsophila paniculata L.), an ornamental used in commercial cut-flower production (Cooksey 1986), and beet (Beta vulgaris L.) (Burr et al. 1991). Infection by Erwinia herbicola pv. gypsophilae (Ehg) is initiated at wound sites, mainly in the crown region of the stem. The host range of Ehg is restricted to gypsophila (Volcani 1985) whereas, in contrast to Ehg, the beet pathovar Erwinia herbicola pv. betae $(E h b)$ generates galls on beet as well as on gypsophila (Burr et al. 1991). The pathogenicity of both pathovars is associated with a similar indigenous plasmid (pPATH) of approximately $150 \mathrm{~kb}$ that is exclusively present in all the

Corresponding authors: I. Barash, E-mail: Isaaci@post.tau.ac.il; S. Manulis, E-mail: vpshula@volcani.agri.gov.il

Nucleotide and/or amino acid sequence data have been submitted to GenBank as accession number U61275. pathogenic strains (Manulis et al. 1991a; S. Manulis and I. Barash, unpublished).

What causes E. herbicola to switch from being an epiphyte on many different plants to being a pathogen, and what determinants are responsible for host range? An initial answer to the first question was recently obtained by demonstrating the presence of a functional hrp cluster on the pPATH, with high homology and collinearity to the hrp genes of E. amylovora (Nizan et al. 1997; R. Nizan, unpublished). Superimposed on the hrp system were the genes encoding phytohormone synthesis. Ehg possesses two major pathways for indole-3-acetic acid (IAA) biosynthesis: the indole-3-acetamide (IAM) pathway, which is present only in pathogenic strains, and the indole-3-pyruvate pathway, which is present in both pathogenic and nonpathogenic strains (Manulis et al. 1991b, 1997). In addition, only the pathogenic strains produced cytokinins (Lichter et al. 1995a; Manulis et al. 1997). Inactivation of IAA production through the IAM pathway (Clark et al. 1993) or of cytokinin biosynthesis (Lichter et al. 1995a), or simultaneous inactivation of the two IAA pathways and cytokinin production (Manulis et al. 1998), caused a substantial reduction in gall size but did not eliminate gall initiation. These findings led to the assumption that gall initiation is triggered by virulence factors other than IAA or cytokinins, secreted by the pathogen.

The molecular basis for host specificity in gram-negative, phytopathogenic bacteria has been a subject of intensive investigation. Most investigations have focused on negativeacting factors that restrict host range by provoking the hypersensitive response (HR) (Long and Staskawicz 1993; Dangl 1994; Leach and White 1996). These negative determinants include the products of the avirulence (avr) genes and harpins (Alfano and Collmer 1996). In contrast, a few reports have suggested that host range is governed by the presence of positive-acting factors encoded by host-specific virulence $(h s v)$ genes (Ma et al. 1988; Salch and Shaw 1988; Waney et al. 1991; Gabriel 1989). The present paper describes the isolation and characterization of a host-specific virulence gene from pPATH, which determines pathogenicity on gypsophila.

\section{RESULTS}

Isolation, sequence analysis, and expression of the pathogenicity gene $h s v G$.

The transposon-reporter Tn3-Spice was used to generate nonpathogenic mutants on the cosmid clone pLA150 derived 
from the pPATH of Ehg 824-1(Lichter et al. 1995a). A cluster of six marker exchange, nonpathogenic mutants designated as EhgMx (\# = B45; A30; 14; B35; 24; B10) was identified on a 3.2-kb NdeI DNA fragment located immediately downstream from the phytohormone biosynthetic genes (Fig. 1). The maximal extent of the putative gene on the right end of the fragment was defined by the Tn3-Spice insertion Ehg824-1Mx4, which retained full pathogenicity. The location of these mutants was determined by mapping with multiple restriction enzymes, hybridization, and polymerase chain reaction (PCR), as described in Materials and Methods. Two additional, nonpathogenic mutants (i.e., EhgMxPI and PII) were obtained by inserting a kanamycinresistance cassette into the two PstI sites of the 3.2-kb NdeI fragment (Fig. 1). The nonpathogenic mutants spanned through an approximately $2-\mathrm{kb}$ fragment that was flanked by two IS1327 elements (Lichter et al. 1996). All the nonpathogenic mutants were restored to full pathogenicity in trans by either pLA150 or pLA-Nd3.2 (Fig. 1).

The 3.2-kb NdeI DNA fragment was subcloned into pBS $\left(\mathrm{KS}^{+}\right)$to yield pMBV-Nd3.2, and subjected to sequence analysis of both strands. A single open reading frame (ORF) of $2 \mathrm{~kb}$ was found $340 \mathrm{bp}$ downstream from the termination codon of IS1327 and predicted a protein with 671 amino acids and a molecular mass of $71.3 \mathrm{kDa}$ (Fig. 2). A potential ribosome binding site, 5'-CGAGA-3', was found 7 bp upstream from the translation start codon, whereas a putative hrp box, 5'GGAACC- $\mathrm{N}_{15}$-TTACA-3', was identified 65 bp upstream from the start codon. The predicted ORF protein lacked an N- terminal signal peptide and any likely membrane-spanning domains. The ORF had no significant homology to known genes. The nucleotide sequence of the 3.2-kb NdeI fragment has been submitted to GenBank as accession number U61275. Since, as will be further described, this putative gene was found to encode a host-specific virulence factor for gypsophila it was designated as $h s v G$.

The complete $h s v G$ ORF was cloned into the $\mathrm{T} 7$ promoterdriven vector pET-11a to yield pET2K and expressed as described in Materials and Methods. Proteins of lysed cells containing either pET2K or pET-11a in the presence or absence of isopropyl- $\beta$-D-thiogalactopyranoside (IPTG) were resolved on sodium dodecyl sulfate-polyacrylamide gel electrophoresis (SDS-PAGE). Results shown in Figure 3 demonstrate the appearance of a strong protein band with an apparent molecular mass of about $72 \mathrm{kDa}$ only in the presence of pET2K with IPTG. This band was absent in identical cells that were grown without IPTG and in cells containing the vector alone in the presence of IPTG. The expressed protein corresponded in size to the expected deduced protein of the $h s v G$ sequence.

\section{Phenotypic expression of $h s v G$ in gypsophila.}

Insertional mutants in $h s v G$ eliminated gall formation on either gypsophila cuttings or whole seedlings that were inoculated with $10^{7} \mathrm{CFU} / \mathrm{ml}$. However, inoculation with a higher bacterial concentration of $10^{10} \mathrm{CFU} / \mathrm{ml}$ resulted in the appearance of a crown around the cutting edge (Fig. 4). The size of the crown was directly related to the distance of the

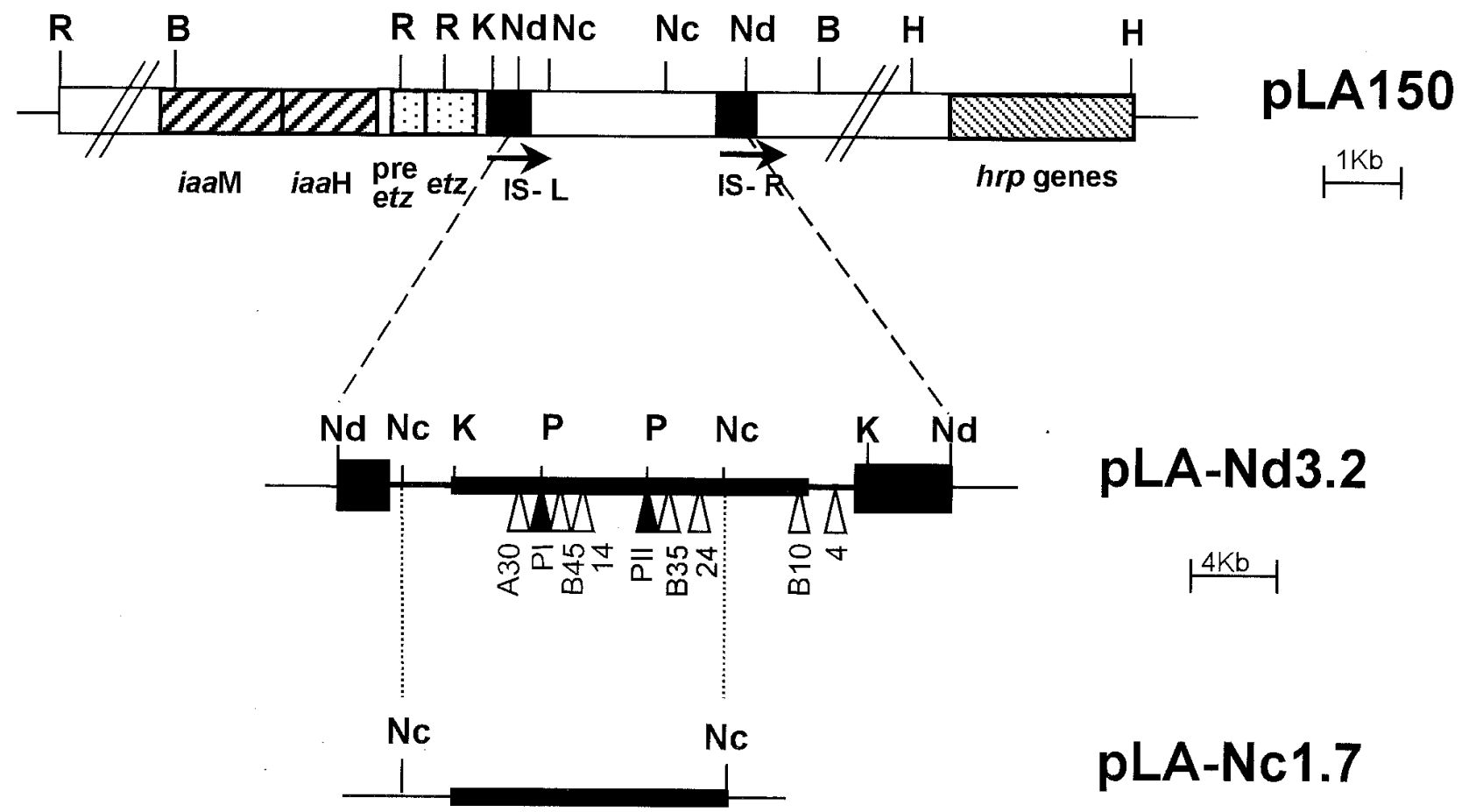

Fig. 1. Physical map of the cosmid clone pLA150, a derivative of pPATH, and the $h s v G$ locus. pLA-Nd3.2 contains a 3.2-kb NdeI fragment of pLA150 cloned into pLAFR3. pLA-Nc1.7 contains a 1.7-kb $N c o$ I fragment of pLA-Nd3.2 cloned into pLAFR3. The apparent open reading frame of $h s v G$ is indicated by bold line. Marker exchange mutants obtained by Tn3-Spice are indicated by open triangles and marked as Ehg824-1Mx(\#); \# = B45, A30, 14, $\mathrm{B} 35, \mathrm{~B} 10$, and 4. Black triangles (Ehg824-1MxPI and PII) are marker exchange mutants obtained by insertion of kanamycin cassette. iaaM and iaaH are indole-3-acetic acid (IAA) biosynthetic genes (Clark et al. 1993), pre-etz and etz are cytokinin biosynthetic genes (Lichter et al.1995a), IS is the insertion element IS1327, L-left, R-right (Lichter et al. 1996), and hrp genes (Nizan et al. 1997). Abbreviations: R, EcoRI; H, HindIII; K, KpnI; Nd, NdeI; Nc, NcoI; B, BamHI; P, PstI. 
NdeI

1 CCATATGATACGCAAAGGGCAGTATAAACATCCGCAGGGGGAACGGTTGTCACCGGCAGAACAATTCTATCTTTTGATTGACTGAAAACAGATTACGCA

101 GCTTTTGCTGACTTACTGCCGTTAATGCGGCAGAGCCGTAAGTTTAGTGTCCTGATPATTCAACCACTACAAAGTGTCCATGGCAGAAACGCGGGAAAA

201 ATAAAAGACGGTCTGTATGTGAGGCTMTCGCCTGTTCTGCGTCTGCCGGCGGGATATGACTCAGCCTTTCCAGTAGCCGTCGATTTTGTACCTCCGTTGA

301 TGCGCATGAACACATAACGGGGTTTATGCCGGAACCGCCGGGCGGTTITCGTTACAAAAGAGGGAGCAT"TAGCGCCGACTTTAGCGGTCTGCCATTAAC SD?

401

CTGACTCCTGACGAGACACCAGCATGTGGAACAACATTAACCCGTACGGCAGGCTTCCCGTAAACAGCCGGGGAGCTGATGAAACTCCACCGGCGGCAGA $\begin{array}{llllllllllllllllllllllllllll}M & W & N & N & I & N & P & Y & G & R & L & P & V & N & S & R & G & A & D & E & T & P & P & A & A & D\end{array}$

501

CCCGCATCCTCAGGGTACCGCCGGCGGCACGCCACCGCTCCGGGACGACCCCGGTGCCGCGCCCTATCCTGAGGATGAGGTGCTCACGGAGTGGTTTTGT

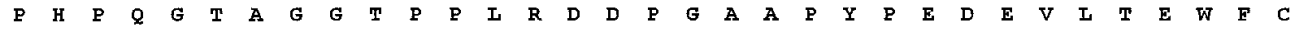

601 GACTGCGCCACCGCTGGCCGCACCCGCCAGCAGGTGGCCAGTGATTACGGATGGGCCCTGCGCAGGTTCAGCGGCTTTCTCAGCCTGAACGGGCTGCCCG

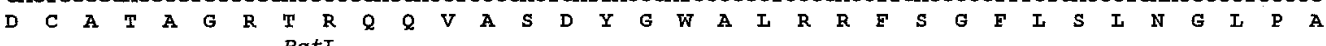
PstI

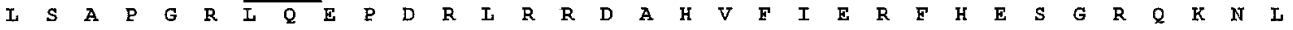

CATACCGGCGCTGAACCGCCTCACCGAGCTGGCGGCGTCGGGAGAGGACAGCATCACGATACGCGGGTCGCAGAGACCCCGGCTGAAGGTTCCCGACGCG $\begin{array}{lllllllllllllllllllllllllllllllll}\mathbf{I} & \mathbf{P} & \mathbf{A} & \mathbf{L} & \mathbf{N} & \mathbf{R} & \mathbf{L} & \mathbf{T} & \mathbf{E} & \mathbf{I} & \mathbf{A} & \mathbf{A} & \mathbf{S} & \mathbf{G} & \mathbf{E} & \mathbf{D} & \mathbf{S} & \mathbf{I} & \mathbf{T} & \mathbf{I} & \mathbf{R} & \mathbf{G} & \mathbf{S} & \mathbf{Q} & \mathbf{R} & \mathbf{P} & \mathbf{R} & \mathbf{L} & \mathbf{K} & \mathbf{V} & \mathbf{P} & \mathbf{D} & \mathbf{A}\end{array}$ SacII

GACGGGGCGCTGATTAAGGGGGCGTTTCCGGGTCTGCCCGCGGGCCCAGGCAGGGACATTTATAGCGTGAACCTCAGAAATGCCGCCCGGTCCCTCAGCG

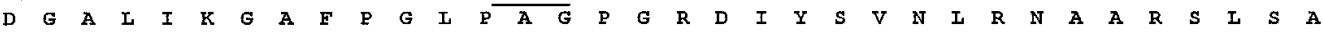
CCTGGCTTCACGAAAACGGCAGGCCCGGGCTGAGCGAIACCGCTTACCTGMTCTCGGAGCAGGCAGGCGCGGACGCCGGTGCGTPCTCCCGGGCTCATCC $\begin{array}{llllllllllllllllllllllllllllllllllll}W & \text { L } & H & \text { E } & \text { N } & G & \text { R } & \text { P } & \text { G } & \text { L } & \text { S } & \text { D } & \text { T } & \text { A } & \text { Y } & \text { L } & \text { F } & \text { S } & \text { E } & \text { Q } & \text { A } & \text { G } & \text { A } & \text { D } & \text { A } & \text { G } & \text { A } & \text { E } & \text { S } & \text { R } & \text { A } & H & \text { H }\end{array}$ $\begin{array}{lllllllllllllllllllllllllllllllllll}\mathbf{A} & \mathbf{N} & \mathbf{A} & \mathbf{G} & \mathbf{R} & \mathbf{V} & \mathbf{N} & \mathbf{M} & \mathbf{I} & \mathbf{L} & \mathbf{A} & \mathbf{H} & \mathbf{L} & \mathbf{R} & \mathbf{A} & \mathbf{H} & \mathbf{A} & \mathbf{R} & \mathbf{G} & \mathbf{E} & \mathbf{V} & \mathbf{P} & \mathbf{H} & \mathbf{V} & \mathbf{G} & \mathbf{R} & \mathbf{L} & \mathbf{Q} & \mathbf{N} & \mathbf{T} & \mathbf{R} & \mathbf{T} & \mathbf{I}\end{array}$

1201 CCGCTGGCAGACCAGCGGCTGGCCCTGGCGTACCTGGGTATCGCGAAAGACCTCGCACGGCAGGCCGGCACAGTGTATAAAAAAAACTCAAACGGCCATG

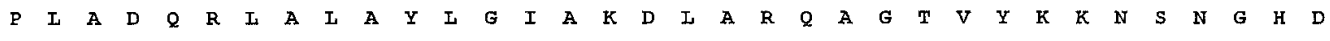

ACTCCATTGACAAAAAAGCCTCTCAGTIAAGGTCATTCAGCGCCTGGCGCACGGCCAGGGGCCTCCCCGCCCTGACCGACCACCTTCATGACCCGGGGCT $\begin{array}{llllllllllllllllllllllllllllllllll}S & I & D & K & K & A & S & Q & I & R & S & F & S & A & \text { W } & R & \text { T } & \text { A } & \text { R } & G & \text { I } & \text { P } & \text { A } & \text { I } & \text { T } & \text { D } & \text { H } & \text { I } & \text { H } & \text { D } & \text { P } & \text { G } & \bar{I}\end{array}$ PstI

1401 GCAGATGGACATGGACATGTACACCGAGgATAAATATCAGAGAAGTCAGACCAACGgGCGGTCCGCTGGCAGCAGCACGGCCAGGTCGGCACGATCCAGG

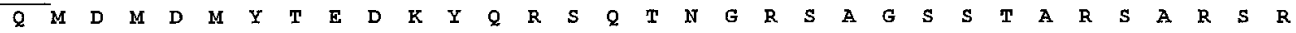
SacI

1501 CTGAGCTCCGCACTGAAAACACTTCAGACCCGCTTTCCGCCGGGAACCCCGTCACCGTCCCGGAGGCACCGGCGGAGTCGTTCGGGCTCCCCGGCTCAG

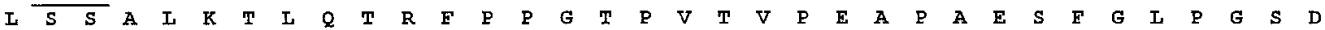

1601 ACTGGTCAGGCTGGGACATGAGCCTGTCCGTCCCCGGCGCGGACGGCGGCCCTGCGCCGGCAGACAGCGATTCCGTGTTCGGGGGCCTGGCGCCGCTGGA $\begin{array}{lllllllllllllllllllllllllllllllllll}\text { W } & S & G & W & D & M & S & \text { L } & S & V & \text { P } & G & \text { A } & \text { D } & \text { G } & \text { G } & \text { P } & \text { A } & \text { P } & \text { A } & \text { D } & \text { S } & \text { D } & \text { S } & \text { V } & \text { F } & \text { G } & \text { G } & \text { I } & \text { A } & \text { P } & \text { L } & \text { D }\end{array}$

1701 CTCCCGCGAGCGCTTTTCCTCTGACGGACTTTCCGGTGCACTGGCCCCTGGCCTTCCGGAGACCGGCGAGGTGAACCGTCCCGTCCCGGAGGCACCGGCG $\begin{array}{lllllllllllllllllllllllllllllllll}\mathbf{S} & \mathbf{R} & \mathbf{E} & \mathbf{R} & \mathbf{F} & \mathbf{S} & \mathbf{S} & \mathbf{D} & \mathbf{G} & \mathbf{L} & \mathbf{S} & \mathbf{G} & \mathbf{A} & \mathbf{L} & \mathbf{A} & \mathbf{P} & \mathbf{G} & \mathbf{L} & \mathbf{P} & \mathbf{E} & \mathrm{T} & \mathbf{G} & \mathbf{E} & \mathbf{V} & \mathbf{N} & \mathbf{R} & \mathbf{P} & \mathbf{V} & \mathbf{P} & \mathbf{E} & \mathbf{A} & \mathbf{P} & \mathbf{A}\end{array}$ 1801 GAATCGTTCGCGCTCCCCGGCTCAGACTGGTCAGGCTGGGGCATGAGCCTGTCCCTCGGTGGCCATGGTCCAGCAGACAGCGATTCCGTGTTCGGGGGCC

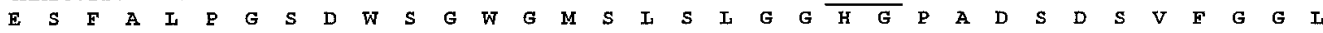

1901 TGGCGCCGCTGGACTCCCGCGAGCGCTTTTCCTCCGGCGGGCTCTCCGGTACACCGGCCTCCGGCCTTCCGGAGACCGGCGAGGTGAACCGTCCCGGCCC

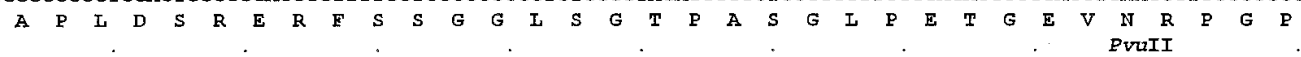
GGACGGGGCTCCTTTCGTGAGCATGCGCGACGCGGTCCCGCCCTICCGTCCCGACGGGGTGGGTITCGCCAGCGGCGAGGGGTTCAGCTGCCTGCTGGAC $\begin{array}{lllllllllllllllllllllllllllllllllll}D & G & A & P & F & V & S & M & R & D & A & V & P & P & F & \text { R } & \text { P } & \text { D } & G & V & G & F & A & S & G & E & G & F & S & C & I & I & D\end{array}$

2101 AGCATCCTCCAGGGCTACCACAACATCCGGCGCGGGCATGGCGCGCCACGGGGGCTGACGGACTGGCTGGACGGAGAGGTCCGGCGGGTCCGCGAGGCGC $\begin{array}{lllllllllllllllllllllllllllllllllllll}\mathbf{S} & I & \mathbf{I} & \mathbf{Q} & \mathbf{G} & \mathbf{Y} & \mathbf{H} & \mathbf{N} & \mathbf{I} & \mathbf{R} & \mathbf{R} & \mathbf{G} & \mathbf{H} & \mathbf{G} & \mathbf{A} & \mathbf{P} & \mathbf{R} & \mathbf{G} & \mathbf{L} & \mathbf{T} & \mathbf{D} & \mathbf{W} & \mathbf{L} & \mathbf{D} & \mathbf{G} & \mathbf{E} & \mathbf{V} & \mathbf{R} & \mathbf{R} & \mathbf{V} & \mathbf{R} & \mathbf{E} & \mathbf{A} & \mathbf{I}\end{array}$ TGTCGGCGCAGGGGGTTGACCTGGTGCCGGCCCGGGGGAATMTGATATTTACGGCGGTCCAGGCAGCTACCTTGCCGGGGCAATGGGCCTCCGGCTGCA $\begin{array}{llllllllllllllllllllllllllllllllll}S & A & \& & G & V & D & I & V & P & A & R & G & E & I & D & I & Y & G & G & P & G & S & Y & I & A & G & A & M & G & I & R & \bar{I} & Q\end{array}$

2301 GGTGATTCAGGCGGAGIITCAGGAGGAGCCGGACGGGACGTACGTGAGGTACACGGCACACCCGGAAATCGGCGAGGCGGGCGGGCGGGCTGTCAGGCTG $\begin{array}{ccllllllllllllllllllllllllllllllll}-V & I & Q & A & E & F & Q & E & E & P & D & G & T & Y & V & R & Y & T & A & H & P & E & I & G & E & A & G & G & R & A & V & R & I\end{array}$

2401 CTGCACACGCCGGGCCACTTTCAGCCGCTCTGGGGGTGAAGGCGGGCAACGTCATCATTCTGGGGTGCCCGGCATTACCGCTGAAAGTGAACGGCTCTGT $\begin{array}{llllllllllllll}\text { L } & \text { H } & \text { T } & \text { P } & \text { G } & \text { H } & \text { F } & \text { Q } & \text { P } & \text { L } & \text { W } & \text { G } & \text { * }\end{array}$

2501 CGCATTAAGGAGTCGTCAGGTAACATAATACTGTTTTITITTMCGATGTCCCTGCCGATGTCTCTTATCCGAAAAGCCTTCAAACGCCTGCATTATCCCG

2601 TCGATATTATTGCCCAGTGCGTTCGCTGGTATCTGGCTTACTCACTCCAGCTTGCGAAATCCTTGAGAAGAGATAATTGCCTTGAGCGGGGGGATTTGTC

2701 GTTTATCAATTCCAACGCTTCACCGCTGGCTCAATCCGGCTGGTACCAACGCTTAGATAAGGCGTTCCGCCGGGTATAAACGTAATCCTGGCCGACGGG

2801 CGGCGAATGGACCGAAACCrACATCCAAAATCAGGGGGGAGTGGAAATACCTGTACCGGGCAGTTGACAGTACGGGGCAGACCATCGACTTCCTGCTGG 2801 CGGCGAATGGACCGAAACCTACATCCAAAATCAGGGGGCAGTGGAAATACCTGTACCGGGCAGTTGACAGTACGGGGAGACCATCGACTTCCTGCTGG 2901 TCGCTAAGCGTGATGCGGCAGCTGCTCTGCGTTTCTICCGCAAGGCTATCCGCAATAACGGGGAACCGGAGGTGGTAACCATTGATAAAAGCGGCGCGA. SacII .

3001 TACCGCGGCTCTGGATACACTIAACGCGGGTAAAGAGATGAAGGAAGTATTATCGTCAGCCAAAGCAGGTATCTGAATAATITGATTGAGCAGGATCAC

3001 TACCGCGGCTCTGGATACACTIAACGCGGGIAAAGGAGATGAAGGAAGIATIATCGICAGCCAAAGCAGGTATCTGAATAATITGATGAGCAGG

3101 CGGAACATCAAACGGCGGATACGACTGATGCTGGGGTTCAAATCATTTNCGCCGGGCGCAGACGATACTGGCCGGCATTGAGTTAATCCATAT

Fig. 2. Nucleotide sequence of the 3.2-kb NdeI fragment and deduced amino acid sequence of $h s v G$. The beginning of the open reading frame and its stop codon are indicated ( $\mathrm{M}$ and *, respectively). The following features are underlined: putative hrp box, proposed Shine-Delgarno (SD) ribosome binding site, and relevant restriction sites. Molecular mass of the predicted peptide is $71.3 \mathrm{kDa}$, containing 671 amino acids. 
insertion from the start codon. Thus, mutants EhgMxB45 and EhgMxA30, which were inserted within the initial $350 \mathrm{bp}$ of the ORF, exhibited only a slight swelling whereas mutants EhgMxB35 and EhgMx24, which were located near the second PstI (700 bp from the $N$ terminus) showed a larger crown (Fig. 4). The largest crown was observed with mutant EhgMxB10, which was located near the C terminus of the $h s v G$. Pathogenicity of all the mutants was fully restored in trans by either pLA150 or pLA-Nd3.2 (Fig. 5). pLA-Nc1.7, which contained only $70.6 \%$ of the $h s v G$ ORF, also restored gall formation in these mutants. However, the restored gall

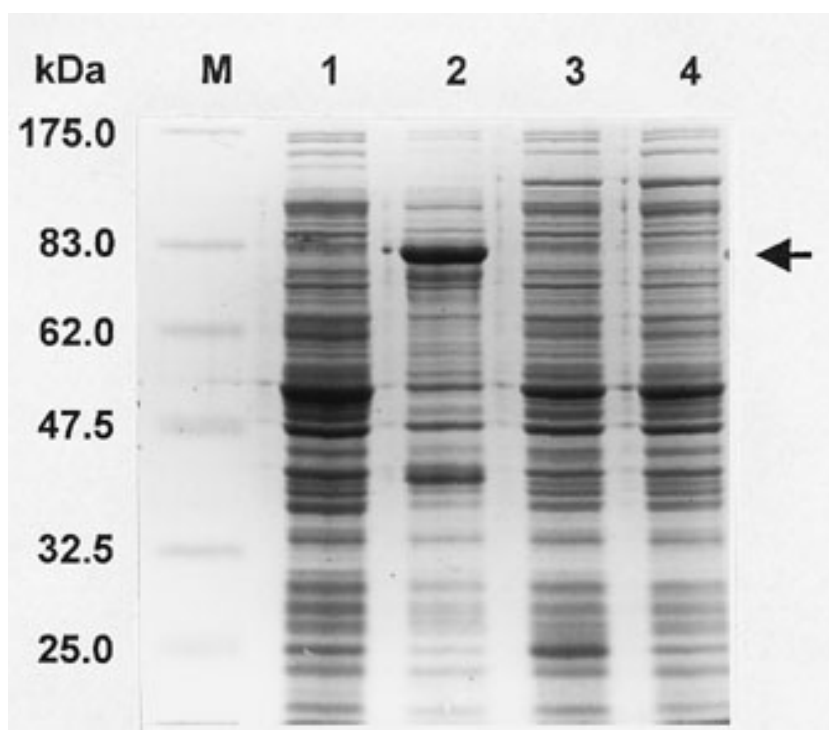

Fig. 3. Expression of $h s v G$ in a $\mathrm{T} 7$ expression system. After growth and induction, as described in Materials and Methods, proteins in 20- $\mu$ l amounts of cell lysates were resolved on sodium dodecyl sulfatepolyacrylamide gel electrophoresis (SDS-PAGE) at $40 \mathrm{~mA}$ until the dye front reached the bottom of the gel. Lane $\mathrm{M}$, prestained broad range protein markers (New England Biolabs, Beverely, MA); Lane 1, Escherichia coli (pET2K); lane 2, E. coli (pET2K) with isopropyl- $\beta-\mathrm{D}-$ thiogalactopyranoside (IPTG); lane 3, E. coli (pET11a) with IPTG; lane 4, E. coli with IPTG. size obtained by pLA-Nc1.7 was considerably lower than that of pLA-Nd3.2 (Fig. 5). The former and latter results may support the notion that the $C$ terminus of the protein is not mandatory for gene expression but that the whole ORF is required for full activity.

The nonpathogenic, marker exchange mutants in $h s v G$ were tested for HR elicitation on tobacco leaves (Nicotiana tabacum L. 'Hicks') as described previously (Nizan et al. 1997). All the mutants caused the HR, as did the wild-type strain (results not shown).

\section{The prevalence of $h s v G$ among gram-negative,} phytopathogenic bacteria.

The total DNA of the tested strains was digested with EcoRI and subjected to Southern blot analysis with the 1.7-kb NcoI fragment as a probe. Results shown in Figure 6 indicate that in addition to the two strains of the gypsophila pathovar, i.e., Ehg824-1 and Ehg350, hsvG sequences are also present in the beet pathovar Ehb4188, but not in the nonpathogenic strain of E. herbicola Eh3-1, which lacks pPATH (Manulis et al. 1991a). Additional pathogenic strains, e.g., Ehg3-1a and Ehb1188, were also found by Southern hybridization to contain $h s v G$, whereas two other nonpathogenic strains, i.e., Eh717-2 and Eh24-8, did not contain this gene (results not shown). It is noteworthy that the band obtained with the two strains of the gypsophila pathovar differed in size from that of the beet pathovar, which may reflect an existing polymorphism between Ehg and Ehb. No hybridization with the $h s v G$ sequence could be detected in Erwinia stewartii, Erwinia amylovora, Ralstonia solanacearum, Xanthomonas campestris pv. campestris (Fig. 6), or Pseudomonas syringae pv. savastanoi (data not shown).

\section{hsvG determines host specificity of $E$. herbicola on gypsophila.}

Since the host range of Ehb includes beet and gypsophila whereas Ehg is restricted to gypsophila, it was of special interest to investigate the function of $h s v G$ in $E h b$. In order to examine the effect of $h s v G$ on the pathogenicity of $E h b$, marker exchange mutants (EhbMx14, EhbMxPI, and $E h b \mathrm{MxPII})$ were generated in Ehb4188. The presence of the

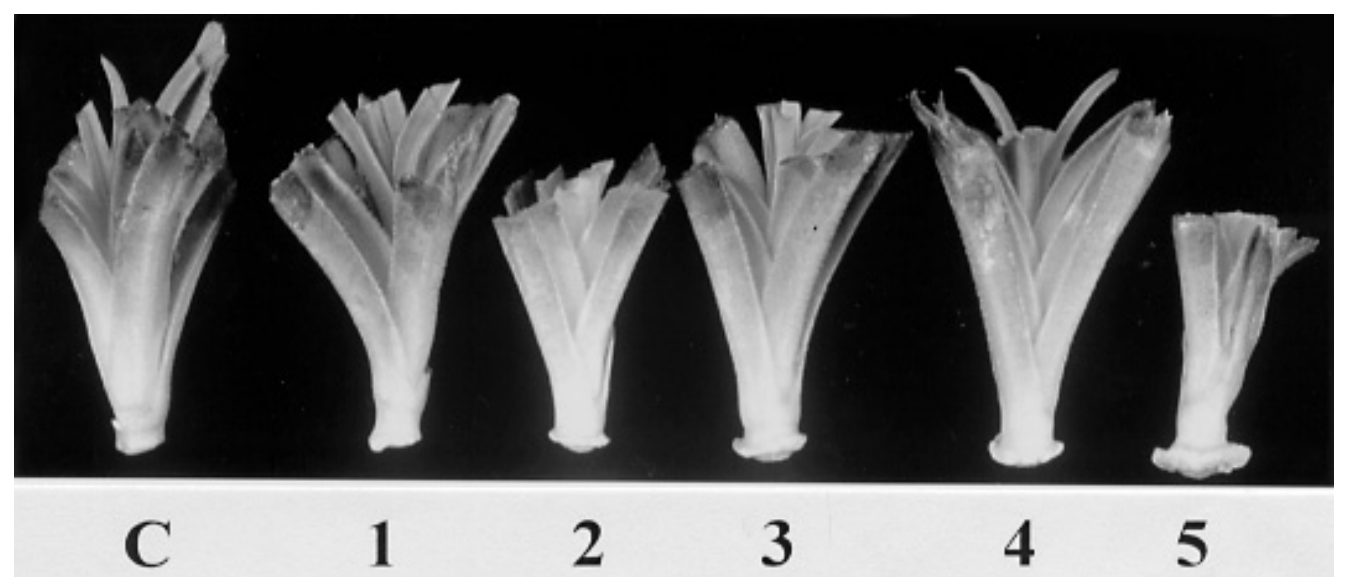

Fig. 4. Phenotypic expression of insertional Tn3-Spice mutants in $h s v G$ following inoculation of gypsophila cuttings. Inoculation was performed with $10^{10} \mathrm{CFU} / \mathrm{ml}$. Location of each mutant on $h s v G$ is given in Figure 1. C: control, cutting not inoculated. Mutants: 1, EhgMxB45; 2, EhgMx14; 3, $E h g \mathrm{MxB} 35 ; 4, E h g \mathrm{Mx} 24$; and 5, EhgMxB10. A crown appears around the cutting edges. Size of the crown was proportional to distance of mutant site from $N$ terminus of the open reading frame. 
insertions in the homologous region of the 3.2-kb NdeI fragment in Ehb4188 was confirmed by hybridization with the 1.7-kb NcoI fragment (results not shown). The obtained mutants were then tested for pathogenicity on beet and gypsophila. Results given in Table 1 clearly demonstrate that these mutants specifically eliminated the pathogenicity of Ehb on gypsophila but fully retained its pathogenicity on beet. On the other hand, the corresponding marker exchange mutants in Ehg were nonpathogenic on both host plants. Consequently, and as already indicated, $h s v G$ could be defined as an $h s v$ gene that determines specificity on gypsophila.

Further studies were aimed at isolating and characterizing the $h s v G$ from Ehb. A cosmid (pLAFR3) library of Ehb4188 plasmids was screened for the presence of $h s v G$ sequence with the 1.7-kb NcoI fragment as a probe. The cosmid pLE564 was isolated and the corresponding 3.2-kb NdeI fragment was subcloned into pBS $\left(\mathrm{KS}^{+}\right)$and sequenced. Comparison of the Ehg and $E h b$ hsv $G$ sequences revealed 98.1 and $98.8 \%$ identity in nucleotides and deduced amino acids, respectively (Fig. 7). It is noteworthy that the eight sites in which differences in base pairs were observed did not interfere with the continuity of the ORF of $h s v G$ in $E h b$ and most of the base displacements were found in the C-terminal region.

Complementation experiments were carried out in order to prove the identical function of $h s v G$ in both pathovars. Thus, pathogenicity of the marker exchange mutants of the gypsophila pathovar (EhgMx14 and EhgMxB45) was restored by either the cosmid clone pLE564 or pLE-Nd3.2 from Ehb. Similarly, the pathogenicity of the marker exchange mutants of the beet pathovar (EhbMxPI and EhbMxPII) was restored by either the cosmid clone pLA150 or its subclone pLA-Nd3.2 from Ehg.

The $h s v G$ in Ehg824-1 is located between two IS1327 elements on pLA150, a derivative of pPATH in Ehg 824-1(Fig. 1). In order to prove that $h s v G$ of $E h b 4188$ also resides on pPATH of the beet pathovar, an insert of $450 \mathrm{bp}$ containing the left-end portion of the 3.2-kb NdeI fragment was obtained by digesting pMBV-Nd3.2 with KpnI (Fig. 1). The 450-bp fragment, which contained a segment of IS1327, was used as a probe for detecting the insertion (IS) element. Results (not shown) demonstrated the presence of IS1327 in pLE564 from which $h s v G$ of $E h b$ was isolated. Since it has been previously shown that IS1327 elements are exclusively present on the pPATHs of the gypsophila and beet pathovars (Lichter et al. 1996), it can be concluded that the $h s v G$ of $E h b$ is also present on this plasmid.

\section{DISCUSSION}

We have isolated and characterized a host-species specificity gene, designated as $h s v G$, that determines the ability of either Ehg or Ehb to incite galls on Gypsophila paniculata. Inactivation of $h s v G$ narrowed the host range of $E h b$ by one host plant (i.e., gypsophila) but did not affect the virulence on the other host plant (i.e., beet) or HR elicitation on tobacco leaves. Since the host range of Ehg is restricted to gypsophila, inactivation of this gene rendered the latter pathovar nonpathogenic. Analysis of the amino acid sequence data bases revealed that, so far, HsvG homologues have not been identified either in other gram-negative, phytopathogenic bacteria or in any other organisms. The predicted protein, which was also

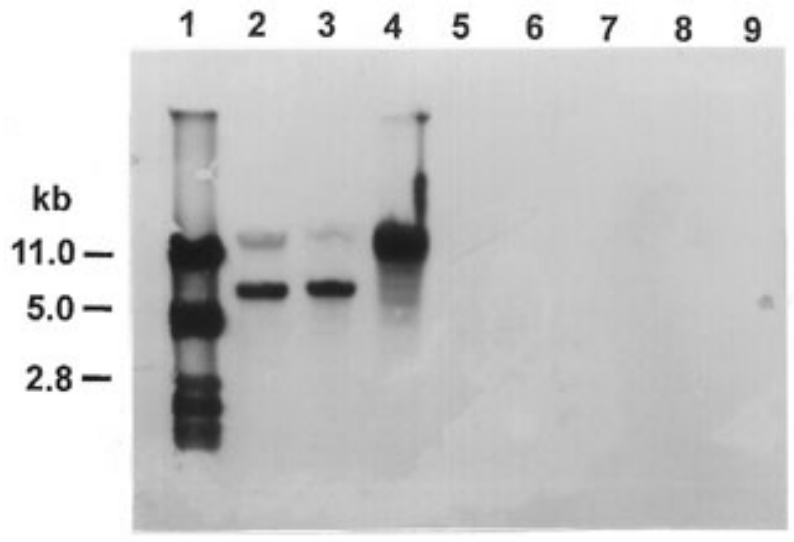

Fig. 6. Southern blot showing distribution of $h s v G$ sequences among the major genera of gram-negative, phytopathogenic bacteria. Total DNA from indicated strains was digested with EcoRI and resolved in 1.2\% agarose gel before blotting and hybridization at moderate stringency with the $1.7-\mathrm{kb} N c o$ I fragment as a probe. Lane $1, \lambda$-PstI DNA digest; lane 2, Ehg824-1 (gypsophila pathovar); lane 3, Ehg350 (gypsophila pathovar); lane 4,Ehb4188 (beet pathovar); lane 5, Erwinia herbicola 31 (a nonpathogenic strain); lane 6, E. amylovora 209; lane 7, E. stewartii DC283; lane 8, Xanthomonas campestris pv. campestris 418; lane 9, Ralstonia solanacearum 1455.

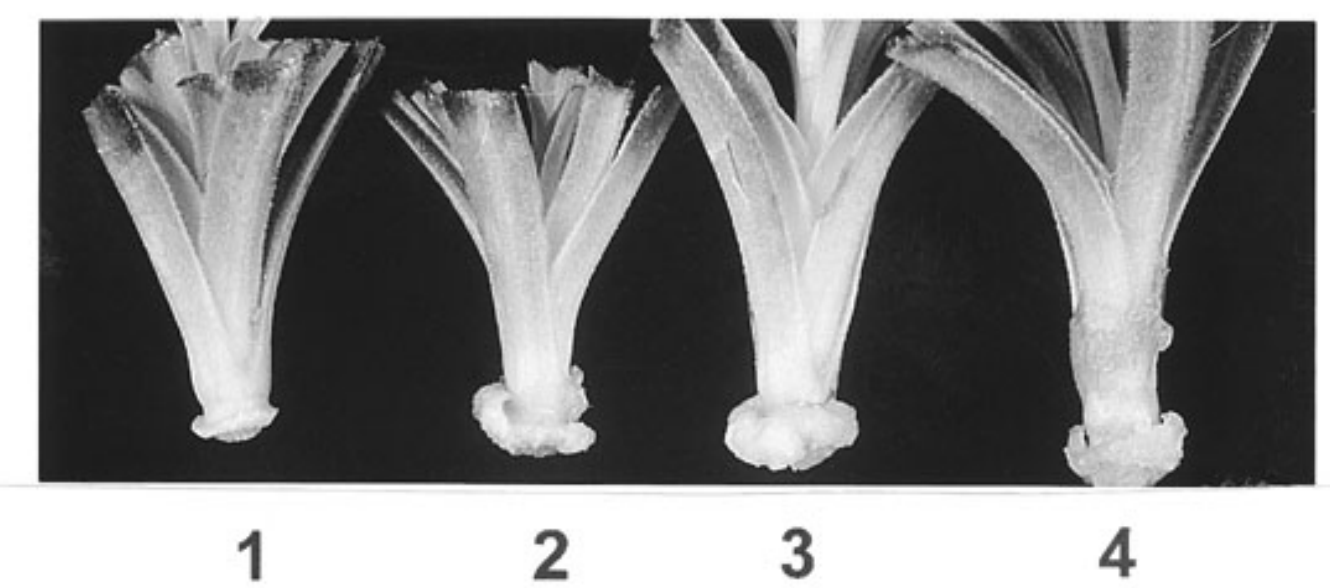

Fig. 5. Restoration in trans of insertional mutant EhgMx14 with pLA-Nc1.7 and pLA-Nd3.2. 1, EhgMx14; 2, EhgMx14+pLA-Nc1.7; 3, EhgMx14 +pLA-Nd3.2; and 4, Ehg824-1. 
synthesized by an expression vector, has a molecular mass of about $72 \mathrm{kDa}$. The observations that $\mathrm{HsvG}$ is predominantly hydrophilic, lacks any membrane-spanning domains, and lacks a cleavable signal peptide, preclude the possibility that it constitutes a membrane protein or that it is being secreted through the type II sec-dependent secretion system (Salmond

Table 1. Effect of insertional mutations on pathogenicity of Erwinia herbicola pv. gypsophilae and E. herbicola pv. betae on gypsophila and beet

\begin{tabular}{lcc}
\hline $\begin{array}{l}\text { Bacterial strains } \\
\text { and mutants }\end{array}$ & $\begin{array}{c}\text { Pathogenicity } \\
\text { on gypsophila }\end{array}$ & $\begin{array}{c}\text { Pathogenicity } \\
\text { on beet }\end{array}$ \\
\hline Ehg824-1 (wild type) & + & - \\
$E h g \mathrm{Mx}(\#)^{\mathrm{a}}$ & - & - \\
$E h b 4188$ (wild type) & + & + \\
$E h b \mathrm{Mx}(\#)$ & - & + \\
\hline
\end{tabular}

${ }^{a} \operatorname{EhgMx}(\#)(\#=14$, PI, PII) and $E h b \mathrm{Mx}(\#)$ (\# = 14, PI, PII) are insertional Tn3-Spice mutants of Ehg824-1 and Ehb4188, respectively. and Reeves 1993). An interesting finding is the detection of a conserved motif ("hrp box") upstream of $h s v G$ that may be recognized by $\mathrm{HrpL}$ (Fig.2). hrpL functions as a positive regulatory gene in directing the expression of hrp genes (Xiao et al. 1994; Wei and Beer 1995). It is a member of the ECF (extra-cytoplasmic functions) subfamily of eubacterial RNA polymerase $\sigma$ factors that recognize consensus promoter sequences. A comparison of the ECF subfamily $\sigma$-dependent putative promoter sequences of $h r p$ genes revealed a striking similarity at the motif corresponding to the -35 region $\left(5^{\prime}-\right.$ GGAACC-3') but an absence of clear similarity at the corresponding -10 recognition region (Wei and Beer 1995). Similar results were obtained with $h s v G$ (Fig. 2). Whether the conserved motif identified upstream of $h s v G$ truly forms an HrpL responsive promoter sequence should await further studies. All the above-mentioned features of $h s v G$ are reminiscent of the $a v r$ genes that have been linked to the activities of the hrp cluster (Leach and White 1996) and that have recently been

Ehg MWNNINPYGRLPVNSRGADETPPAADPHPQGTAGGTPPLRDDPGAAPYPEDEVLTEWFCD

Ehb MWNNINPYGRLPVNSRGADETPPAADPHPQGTAGGTPPLRDDPGAAPYPEDEVLTEWFCD

Ehg CATAGRTRQQVASDYGWALRRFSGFLSLNGLPALSAPGRLQEPDRLRRDAHVFIERFHES

Ehb CATAGRTRQQVASDYGWALRRFSGFLSLNGLPALSAPGRLQEPDRLRRDAHVFIERFHES

Ehg GRQKNLIPALNRLTELAASGEDSITIRGSQRPRLKVPDADGALIKGAFPGLPAGPGRDIY

Ehb GRQKNLIPALNRLTELAASGEDSITIRGSQRPRLKVPDADGALIKGAFPGLPAGPGRDIY

Ehg AHARGEVPHVGRLQNTRTIPLADQRLALAYLGIAKDLARQAGTVYKKNSNGHDSIDKKAS Ehb AHARGEVPHVGRLQNTRTI PLADQRLALAYLGIAKDLARQAGTVYKKNSNGHDS IDKKAS

QLRSFSAWRTARGLPALTDHLHDPGLQAPMDMY TEDKYQRSQTNGRSAGSSTARSARSRL

Ehg GLAPLDSRERFSSDGLSGALAPGLPETGEVNRPVPEAPAESFALPGSDWSGWGMSLSLGG

Ehg HGPADSDSVFGGLAPLDSRERFSSGGLSGTPASGLPETGEVNRPGPDGAPFVSMRDAVPP

Ehg FRPDGVGFASGEGF SCLLDSILQGYHNIRRGHGAPRGLTDWLDGEVRRVREALSAQGVDL Ehb FRPDGVGFASGEGLSCLLDSILQGYHNIRRGHGAPRGLTDWLDGEVRRVREALSAQGVDI 
shown to deliver the Avr proteins directly into the host plant cell through the type III secretion system (Gopalan et al. 1996; Leister et al. 1996; Van den Ackerveken et al. 1996).

Evidence obtained from restoration of pathogenicity to insertional mutants in $h s v G$ as well as from the phenotypic expression of these mutants in gypsophila cuttings suggests that, although the entire HsvG protein may be needed for full virulence, its C-terminal region is not essential for expressing partial virulence. Thus, restoration of mutants with pLANc1.7, which contained only $70 \%$ of the $h s v G$ ORF (starting from the translation start codon), resulted in formation of galls, albeit smaller galls than resulted from restoration of mutants with the full ORF (Fig. 5). Additional conformation of the dispensability of the C-terminal region could be gained from studies on crown appearance at the foot base of gypsophila cuttings following inoculation with an excessive concentration of the nonpathogenic mutants (Fig. 4). The size of the crown was correlated with the distance of the mutant's site from the start of the ORF. It is also noteworthy that most of the sequence alterations in the deduced proteins of $h s v G$ in Ehg, compared with Ehb, were detected in the C-terminal region, whereas the $\mathrm{N}$-terminal region remained almost identical in the two pathovars (Fig. 7).

The crown phenomenon observed in gypsophila cuttings during the phenotypic expression of mutants is intriguing and deserves further consideration. At the outset it should be emphasized that the conditions used for crown formation were highly artificial, namely, inoculation of gypsophila cuttings with bacterial concentration at least three orders of magnitude higher than that required for gall formation by the wild-type strain. Although the mechanism that triggers crown development is not understood, it might be speculated that it is incited by the disrupted HsvG, which acts as an elicitor. Accordingly, we suggest that a rudimentary binding activity to a hypothetical plant receptor is still retained by the modified elicitor and is capable of eliciting a plant morphogenic response, which leads to crown rather than gall formation. The extent of the elicitation activity appears to be influenced by the site of the insertional mutant on the ORF as described above.

Biotrophic microbial pathogens generally appear to be limited in their interactions to a particular plant species, genus, or family, or, occasionally, to members of different families. Two concepts, which are not necessarily mutually exclusive, have been proposed to determine the host range of plant-pathogenic bacteria. The first is based on host range restriction by determinants that confer incompatibility. This view has mainly evolved from numerous studies on the function and extent of the role(s) that $a v r$ genes play in plant-microbe interactions (Dangl 1994; Leach and White 1996). Dominant $a v r$ genes were originally defined in the context of race- and cultivarspecific interactions and were shown to require the presence of specific resistance $(\mathrm{R})$ genes in the host. These negative (incompatible) interactions were termed gene-for-gene interactions (Keen 1990). However, it has also been demonstrated that single cloned $a v r$ genes from a pathogen of one host species can cause an otherwise virulent pathogen of another host species to become avirulent on its own host (Whalen et al. 1988; Kobayashi et al. 1989; Whalen et al. 1991; Dangl 1992; Fillingham et al. 1992; Swarup et al. 1992). These data indicated that $a v r$ genes not only limit bacterial host range within a host plant species but many are also genetically dominant determinants in limiting the host range of phytopathogenic bacteria on multiple plant species (Keen 1990; Dangl 1994). Interestingly, although the hrp-encoded harpins that elicit HR on nonhost plants could be considered candidates for host restriction, their contribution to host range determination is not clear (Alfano and Collmer 1996). It should also be pointed out that the negative-acting factors involved in host range determination have been demonstrated to be superimposed on hrp genes that are responsible for "basic pathogenicity" (Leach and White 1996).

An alternative view of host range determination, based on positive-functioning $h s v$ genes, has been proposed (Gabriel 1989). This notion was inferred from the primary function of positive-acting, host-specific nod genes of Rhizobium 1996) and from the argument that the role of $a v r$ genes in nonhost incompatibility is generally gratuitous, so that they may not be suitable to evolve as primary determinants of host specificity (Gabriel 1989; Waney et al. 1991). However, evidence supporting the role of positive-acting virulence genes in host range determination of phytopathogenic bacteria has been very scanty. Such genes have so far been demonstrated only in Pseudomonas syringae pv. tabaci for host specificity on tobacco (Salch and Shaw 1988), in Ralstonia solanacearum for host specificity on peanut (Ma et al. 1988), and in genes conferring host specificity in Xanthomonas campestris pv. translucens for various graminaceous host genera (Waney et al. 1991). Although all the above-mentioned reports clearly demonstrated the presence of positive-acting, $h s v$ genes, in none of these studies had any of these putative $h s v$ genes been characterized.

We hypothesize that host specificity of Ehg and Ehb may be determined either by $h s v$ genes only or by interaction between $h s v$ and $a v r$ genes. Thus, the differing host ranges of the beet and gypsophila pathovars can be assigned to the presence of two different $h s v$ genes, specific for beet and gypsophila, respectively, in $E h b$ and the absence of the beet-specific $h s v$ in Ehg. Alternatively, each pathovar may contain both the gypsophila-specific and beet-specific hsv genes, while Ehg possesses a heterologous avr that causes this pathovar to become incompatible with beet, so that the expression of the beetspecific $h s v$ is suppressed. Experiments are now in progress to distinguish between these two alternatives.

As indicated above, gall initiation by Ehg has been shown to be independent of IAA and cytokinin production by the pathogen. It has been reported that host-specific Nod factors of Rhizobium spp. act as species-specific morphogens of plants and cause initiation of host root cortical cell division and root hair cell growth (Long 996). It is tempting to speculate that the binding of HsvG to a host-plant receptor leads to production of morphogens that cause hypertrophy and gall initiation. Finding the presumed receptor of HsvG in gypsophila would be most useful in understanding the mechanism of gall formation.

\section{MATERIALS AND METHODS}

\section{Bacterial strains and growth conditions.}

The bacterial strains, cosmids, and plasmids used in this study are presented in Table 2. Bacteria were grown in LuriaBertani (LB) broth or LB agar plates with appropriate antibiotics, at $28^{\circ} \mathrm{C}$ for E. herbicola and at $37^{\circ} \mathrm{C}$ for Escherichia coli. Genetic manipulations were carried out in E. coli DH10B (GIBCO BRL, Gaithersburg, MD). Antibiotics were used in 
the following concentrations ( $\mu \mathrm{g}$ per $\mathrm{ml}$ ): ampicillin (Amp), 100; kanamycin $(\mathrm{Km}), 50$; spectinomycin $(\mathrm{Sp}), 50$; rifampicin (Rif), 100; and tetracycline (Tc), 15.

\section{Pathogenicity tests.}

Pathogenicity tests on cuttings and seedlings of Gypsophila paniculata var. perfecta were essentially as described previously (Manulis et al. 1991a; Lichter et al. 1995a). After removal of an approximately 3-mm section from the bottom of the stem, the cutting was inoculated by dipping into a bacterial suspension of $10^{7} \mathrm{CFU} / \mathrm{ml}$ and placed in vermiculite-filled trays. The greenhouse temperature was maintained at 26 to $29^{\circ} \mathrm{C}$ and high humidity was generated by computercontrolled mist sprinklers as described elsewhere (Lichter et al. 1995a). Gall formation was scored 14 days after inoculation on three or four replicas per strain, in at least three independent experiments. Pathogenicity was also performed on 5week-old gypsophila seedlings grown under a shed net. Inoculation was carried out by injecting $0.05 \mathrm{ml}$ of bacterial suspension with a fine hypodermic needle, through the apex of the seedling and into the stem. Three seedlings per strain were inoculated, and results were obtained from two independent experiments. Symptoms were evaluated according to an arbitrary scale 1 month after inoculation (Lichter et al. 1995a).

Pathogenicity tests on table beet and beet seedlings were performed similarly to Burr et al. (1991). Whole mature beets were soaked in $1 \%$ sodium hypochloride for $10 \mathrm{~min}$ and then washed twice in sterile water. They were then cut into $0.5 \times$ $0.7 \times 0.7 \mathrm{~cm}$ blocks, each of which was placed on sterile $1.5 \%$ water agar in a petri dish. Inoculation was carried out with an overnight culture grown on LB agar by puncturing the bacteria into the top of the cube with a sterile toothpick. The dishes were incubated for 5 days at $28^{\circ} \mathrm{C}$ and then tested for gall formation. Three beet blocks were used for each strain, and the experiment was performed at least three times. Pathogenicity tests were also carried out on 3-week-old beet seedlings (Beta vulgaris var. Red Egyptian) grown on vermiculite. Inoculation was carried out by puncturing the stem with a sterile nee-

Table 2. Bacterial strains, cosmids, and plasmids used in this study

\begin{tabular}{|c|c|c|}
\hline Strain/plasmid & Relevant characteristics ${ }^{a}$ & Reference or source \\
\hline \multicolumn{3}{|l|}{ Escherichia coli } \\
\hline DH10B & $\begin{array}{l}\mathrm{F}^{-} m r c \mathrm{~A} \Delta(m r r \text { hsd } \mathrm{RMS}-m c r \mathrm{BC}) \phi 80 \mathrm{~d} l a c \mathrm{Z} \Delta \mathrm{M} 15 \\
\quad \Delta l a c \mathrm{X} 74 \text { deo } \mathrm{R} \text { recA1 ara } 139 \Delta(\text { ara leu }) 7697 \text { gal } \mathrm{U} \\
\quad \text { galK } \lambda^{-} \text {rpsL end } 1 \text { nup } \mathrm{G}\end{array}$ & GIBCO BRL, Gaithersburg, MD \\
\hline HMS174(DE3) & $\mathrm{F}^{-}$rec $\mathrm{A} h s d \mathrm{R}\left(\mathrm{rK} 12^{-} \mathrm{mK} 12^{+}\right) \mathrm{Rif}^{\mathrm{r}}(\mathrm{DE} 3)$ & Novagen, Madison, WI \\
\hline Erwinia stewartii & nal $^{\mathrm{r}}$, wild-type pathogenic strain DC283 & $\begin{array}{l}\text { D. Coplin , Ohio State University, } \\
\text { U.S.A. }\end{array}$ \\
\hline Erwinia amylovora & Wild-type pathogenic strain 209 & S. Manulis, Volcani Center, Israel \\
\hline Xanthomonas campestris pv. campestris & Wild-type pathogenic strain 418 & S. Manulis, Volcani Center, I srael \\
\hline Ralstonia solanacearum & Wild-type pathogenic strain 1455 & $\begin{array}{l}\text { E. Levi, Ministry of Agriculture, } \\
\text { Israel }\end{array}$ \\
\hline Pseudomonas syringe pv. savastanoi & Wild-type pathogenic strain ITM318 & $\begin{array}{l}\text { N. S. Iacobellis, University of Bari, } \\
\text { Italy }\end{array}$ \\
\hline \multicolumn{3}{|l|}{ Erwinia herbicola pv. gypsophilae (Ehg) } \\
\hline Ehg824-1 & Wild-type pathogenic strain with $\mathrm{Rif}^{\mathrm{r}}$, gypsophila pathovar, serotype I & Manulis et al. 1991a \\
\hline Ehg3-1a & Wild-type pathogenic strain, gypsophila path ovar, serotype I & Manulis et al. 1991a \\
\hline Ehg350 & $\begin{array}{l}\text { Wild-type pathogenic strain with } \mathrm{Rif}^{\mathrm{r}} \text {, gypsophila pathovar, serotype } \\
\text { II }\end{array}$ & Manulis et al. 1991a \\
\hline Eh3-1, Eh717-2, Eh24-8 & Wild-type nonpathogenic strains, serotype I & Manulis et al. 1991a \\
\hline $\begin{array}{l}\operatorname{EhgMx}(\#)(\#=4,14,24, \mathrm{~A} 30, \mathrm{~B} 10 \\
\quad \mathrm{B} 35, \mathrm{~B} 45, \mathrm{PI}, \mathrm{PII})\end{array}$ & $\begin{array}{l}\mathrm{Amp}^{\mathrm{r}}, \mathrm{Sp}^{\mathrm{r}}, \mathrm{Sm}^{\mathrm{r}} \text {, marker exchange mutants on the pathogenicity- } \\
\text { associated plasmid pPATH of Ehg }\end{array}$ & This study \\
\hline EhgMx19 & $\begin{array}{l}\mathrm{Amp}^{\mathrm{r}}, \mathrm{Sp}^{\mathrm{r}}, \mathrm{Sm}^{\mathrm{r}} \text {, marker exchange mutant of insertional } \mathrm{Tn} 3 \text {-Spice in } \\
\text { the } h r p \text { cluster }\end{array}$ & Nitzan et al. 1997 \\
\hline \multicolumn{3}{|l|}{ Erwinia herbicola pv. betae $($ Ehb) } \\
\hline Ehb1188 & Wild-type pathogenic strain, beet pathovar & Burr et al. 1991 \\
\hline Ehb4188 & Wild-type pathogenic strain with $\mathrm{Rif}^{\mathrm{r}}$, beet pathovar & Burr et al. 1991 \\
\hline $\operatorname{EhbMx}(\#)(\#=14, \mathrm{PI}, \mathrm{PII})$ & $\begin{array}{l}\mathrm{Amp}^{\mathrm{r}}, \mathrm{Sp}^{\mathrm{r}}, \mathrm{Sm}^{\mathrm{r}} \text {, marker exchange mutants on the pathogenicity- } \\
\text { associated plasmid pPATH of Ehb }\end{array}$ & This study \\
\hline \multicolumn{3}{|c|}{$e_{-1}$} \\
\hline pLAFR3 & $\mathrm{Tc}^{\mathrm{r}}$, broad-host-range vector $\operatorname{IncP}-1$ rixRK2 ${ }^{+}$lac $\mathrm{Za} \mathrm{Tra}{ }^{-} \mathrm{Mob}^{+} \cos$ & Staskawicz et al. 1987 \\
\hline pLA150 & $\mathrm{Tc}^{\mathrm{r}}$, a $28-\mathrm{kb}$ cosmid of pPATH in pLAFR3 & Lichter et al. 199b \\
\hline pLA-Nc1.7 & $\mathrm{Tc}^{\mathrm{r}}$, a $1.7-\mathrm{kb} N c o$ I fragment of Ehg cloned into pLAFR3 & This study \\
\hline pLA-Nd3.2 & $\mathrm{Tc}^{\mathrm{r}}$, a 3.2-kb NdeI fragment of Ehg cloned into pLAFR3 & This study \\
\hline pLE564 & $\mathrm{Tc}^{\mathrm{r}}$, a 27-kb cosmid of pPATH of Ehb in pLAFR3 & D. Ezra, Volcani Center, Israel \\
\hline pLE-Nd3.2 & $\mathrm{Tc}^{\mathrm{r}}$, a 3.2-kb NdeI fragment of Ehb cloned into pLAFR3 & This study \\
\hline \multicolumn{3}{|l|}{ Plasmids } \\
\hline pBluescript & $\mathrm{Amp}^{\mathrm{r}}$, subcloning and sequencing vector, $\mathrm{KS}^{+}(\mathrm{pBS})$ & Stratagene, La Jolla, CA \\
\hline pRK2073 & $\mathrm{Sp}^{\mathrm{r}}, \mathrm{Sm}^{\mathrm{r}}$, helper plasmid for triparental matings & Ditta et al. 1980 \\
\hline pTn3-Spice & $\mathrm{Amp}^{\mathrm{r}}, \mathrm{Sp}^{\mathrm{r}}, \mathrm{Sm}^{\mathrm{r}}$, clone containing the inaZ reporter gene in $\mathrm{Tn} 3$ & Lindgren et al. 1989 \\
\hline pUC4K & $\mathrm{Km}^{\mathrm{r}}, \mathrm{Amp}^{\mathrm{r}}$, Km gene cassette used for gene disruption & Pharmacia, Uppsala, Sweden \\
\hline pET11a & $\mathrm{Amp}^{\mathrm{r}}$, plasmid for protein over expression & Novagen \\
\hline pMBV-Nc1.7 & $\mathrm{Amp}^{\mathrm{r}}$, a 3.2-kb NdeI fragment cloned into $\mathrm{pBS}$ & This study \\
\hline pMBV-Nd3.2 & $\mathrm{Amp}^{\mathrm{r}}$, a 1.7-kb NcoI fragment cloned into $\mathrm{pBS}$ & This study \\
\hline pMBV-Nd3.2b & $\mathrm{Amp}^{\mathrm{r}}$, a 3.2-kb $N d e \mathrm{I}$ fragment of $E h b$ cloned into $\mathrm{pBS}$ & This study \\
\hline pET2K & $\mathrm{Amp}^{\mathrm{r}}$, a 2-kb fragment from Ehg pPATH in pET11a & This study \\
\hline
\end{tabular}

a Abbreviations: Amp = ampicillin; kanamycin $=\mathrm{Km}$; Rif = rifampicin; Sm = streptomycin; $\mathrm{Sp}=$ spectinomycin; $\mathrm{Tc}=$ tetracycline; $\mathrm{r}=$ resistance. 
dle and applying the bacteria to the wound with a toothpick. The appearance of galls was evaluated after 10 days.

\section{DNA manipulations.}

Isolation of plasmid DNA from E. coli, restriction enzyme digestions, subcloning, transformations, Southern blot analysis, and PCR were carried out by standard procedures (Sambrook et al. 1989) or as recommended by the suppliers. Isolation of plasmid and genomic DNA from E. herbicola was performed as described previously.

\section{DNA sequencing.}

A 3.2-kb NdeI fragment of pLA150 (Fig. 1) was subcloned into $\mathrm{pBS}\left(\mathrm{KS}^{+}\right)$to yield pMBV-Nde3.2. Generation of unidirectional deletions of the fragment was obtained with the "Erase a Base" kit (Promega, Madison, WI). Screening for clones with an appropriate size was carried out by PCR with T3 and T7 primers and verified with restriction enzymes. The entire fragment was sequenced in two directions by the dideoxy chain termination method with the Sequenase 2.0 kit (U.S. Biochemical, Cleveland, OH) and $\alpha-{ }^{35}$ S-dATP (Du Pont, NEN, Boston). The sequence was completed by constructing extra subclones with the restriction enzymes NcoI, PstI, KpnI, and SacII for Ehg (Fig. 2) and PstI, SacI, SacII, and PvuII for Ehb. This was done by automated sequencing with Taq DNA polymerase (Department for Biological Services, Weizmann Institute, Rehovot, Israel). DNA for sequencing was prepared with Wizard Minicolumns (Promega, Madison, WI). Analysis of sequence data for the DNA and deduced protein sequences was done according to the Program Manual for the Wisconsin Package (Version 9, Dec. 1996, Genetic Computer Group, Madison, WI).

\section{Construction of mutants and marker exchange.}

Cosmid libraries of plasmid DNA from Ehg824-1 and Ehb4188 in pLAFR3 were available from previous studies (Lichter et al. 1995a; D. Ezra, unpublished). Insertional mutagenesis was carried out on cosmid clones with the transposon reporter pTn3-Spice as described elsewhere (Lindgren et al. 1989). The mutated cosmids were mobilized to the wildtype strains of Ehg or Ehb by triparental mating with pRK2073 as a helper plasmid (Ditta et al. 1980). Plasmid curing was performed as previously described (Lichter et al. 1995b). The marker exchange mutants were subjected to pathogenicity tests as described above.
The location and orientation of the Tn3-Spice in the nonpathogenic mutants was determined by mapping with multiple restriction enzymes and hybridization with the following two probes: a 1.5-kb BamHI fragment derived from Tn3-Spice, and a 1.7-kb NcoI fragment obtained from pLA150 (Fig. 1). Additional confirmation of the insert location in the mutants was obtained by PCR, with primers based on pLAFR3 and Tn3-Spice for mutated inserts in E. coli and primers based on Tn3-Spice and the 3.2-kb NdeI fragment for E. herbicola (Table 3). Primers were chosen according to the expected location and orientation of the Tn3-Spice insertion in the examined fragment, which were determined by Southern hybridization with the above-mentioned probes.

Site-directed insertional mutagenesis was performed by introducing the kanamycin-resistance gene cassette (KM cassette) into the two PstI sites of the 1.7-kb NcoI fragment in pMBV-Nc1.7 (Fig. 1). Mobilization of the constructs to the wild-type strain and plasmid curing were carried out as described above. These two marker exchange mutants were designated as EhgMxPI and EhgMxPII (Fig. 1). Verification of the insert location in these mutants was performed by digesting the DNA with $\mathrm{NcoI}$ followed by Southern hybridization, with the 1.7-kb NcoI fragment used as a probe.

\section{Expression of $h s v G$ in a bacteriophage T7 RNA polymerase-promoter expression system.}

The T7 promoter-driven system pET (Novagene, Madison, WI) was employed to express the HsvG protein. The ORF of $h s v G$ was amplified by PCR with primers 222 and 1252 (Table 3), which were designed on the basis of the $5^{\prime}$ and $3^{\prime}$ ends, respectively, of this gene (Fig. 2), with an appropriate restriction enzyme sites for cloning. The "Expand HighFidelity PCR system” (Boehringer, Mannheim, Germany) was used to amplify the predicted ORF (2 kb) of $h s v G$. The amplified fragment was digested with $N d e \mathrm{I}$ and $B a m \mathrm{HI}$ and cloned into pET11a through the same restriction sites to form $\mathrm{pET} 2 \mathrm{~K}$. The recombinant plasmid and the vector were transformed into E. coli HMS174 (DE3). For protein expression, a fresh culture of the transformed E. coli (pET2K) was grown in LB at $37^{\circ} \mathrm{C}$ up to an $\mathrm{OD}_{600}=0.5$, prior to the addition of $0.04 \mathrm{mM}$ IPTG. The culture was then grown for an additional $3 \mathrm{~h}$ at $37^{\circ} \mathrm{C}$ and $800 \mu \mathrm{l}$ of cells was centrifuged, resuspended in 50 $\mu 1$ of distilled water, and mixed with $25 \mu \mathrm{l}$ of sample buffer, three times (New England Biolabs, Beverly, MA). Cultures of

Table 3. Sequence and location of primers used in this study ${ }^{\mathrm{a}}$

\begin{tabular}{|c|c|c|c|c|}
\hline$\overline{\text { Primer }}$ & Sequence & Source & Position & Direction \\
\hline 500 & 5'-AGAGGCGTCAGAGGCAG-3' & pTn3-Spice & 64 to $48^{\mathrm{b}}$ & Upstream \\
\hline 367 & $5^{\prime}$-TCTCATGACCAATCCC-3' & pTn3-Spice & 10677 to 10694 & Downstream \\
\hline 53 & 5'-CAAGGCGATTAAGTTGGG-3' & pLAFR3 & 333 to $316^{\mathrm{c}}$ & Upstream \\
\hline 54 & 5'-GAATTGTGAGCGGATAAC-3' & pLAFR3 & 177 to 194 & Downstream \\
\hline lea1 & 5'-GGGAATTCAACCACTACAAAGTGTCC-3' & pLA-Nd3.2 & 160 to $180^{\mathrm{d}}$ & Downstream \\
\hline 651 & $5^{\prime}$-CTTTTCCTCTGACGGACTTTCC- $3^{\prime}$ & pLA-Nd3.2 & 1713 to 1734 & Downstream \\
\hline 769 & 5'-GAGTGAGTAAGCCAGATACC-3' & pLA-Nd3.2 & 2648 to 2628 & Upstream \\
\hline 4148 & 5'-TTAACTGAGAAGCTTTTTAGTCAATGGAGTCATGGCCGTTT-3' & pLA-Nd3.2 & 1340 to 1290 & Uupstream \\
\hline 35107 & 5'-GTGGCCAGTGAATTCGGATGGGCCCTGCGCAGGTT-3' & pLA-Nd3.2 & 634 to 668 & Downstream \\
\hline 1072 & 5'-GCCGTCGACTCCGCCGGTGCCTCC-3' & pLA-Nd3.2 & 1582 to 1563 & Upstream \\
\hline 222 & 5'-GCGAATTCATATGGTGGAACAACATTAACCCG-3' & pLA-Nd3.2 & 424 to 444 & Downstream \\
\hline 252 & 5'-CGGGATCCTCACCCCCAGAGCGGC-3' & pLA-Nd3.2 & 2439 to 2424 & Upstream \\
\hline
\end{tabular}

${ }^{a}$ The primers were synthesized by Biotechnology General, Nes Ziona, Israel.

${ }^{b}$ The position is from the transcription initiation of $\mathrm{p} \operatorname{Tn} 3$-Spice.

${ }^{c}$ The position is from the lac-operon of pLAFR3.

${ }^{\mathrm{d}}$ The position is from the beginning of the $3.2 \mathrm{NdeI}$ fragment of Ehg. 
E. coli (pET2K) without IPTG, E. coli (pET11a) in the presence and absence of IPTG, and nontransformed $E$. coli were used as controls. The samples were heated at $100^{\circ} \mathrm{C}$ for $3 \mathrm{~min}$ and then loaded onto an SDS $10 \%$ polyacrylamide gel. The procedure for SDS-PAGE was performed in a single-concentration minigel as described elsewhere (Ausubel et al. 1995).

\section{ACKNOWLEDGMENTS}

This study was supported by grant US-2816-96 from the US-Israel Binational Agricultural Research and Development Fund (BARD).

\section{LITERATURE CITED}

Alfano, J. R., and Collmer, A. 1996. Bacterial pathogens in plants: Life up against the wall. Plant Cell 8:1683-1698.

Ausubel, F. M., Brent, R., Kingston, R. E., Moore, D. D., Seidman, J. G., Smith, J. A., and Struhl, K. 1995. Current Protocols in Molecular Biology. John Wiley \& Sons, New York.

Burr, T. J., Katz, B. H., Abawi, G. S., and Crosier, D. C. 1991. Comparison of tumorigenic strains of Erwinia hebicola isolated from table beet with E. h. gypsophilae. Plant Dis. 75:855-858.

Clark, E., Manulis, S., Ophir, Y., Barash, I., and Gafni, Y. 1993. Cloning and characterization of $i a a M$ and $i a a H$ from Erwinia herbicola pv. gypsophilae. Phytopathology 83:234-240.

Cooksey, D. A. 1986. Galls of Gypsophila paniculata caused by Erwinia herbicola. Plant Dis. 70:464-468.

Dangl, J. 1992. The major histocompatibility complex a la carte: Are there analogies to plant disease resistance genes on the menu? Plant J. 2:3-11.

Dangl, J. L. 1994. The enigmatic avirulence genes of phytopathogenic bacteria. Curr. Top. Microbiol. Immunol. 192:99-118.

Ditta, G., Stanfield, S., Corbin, D., and Helinsky, D. R. 1980. Broad host range DNA cloning system for gram-negative bacteria: Construction of a gene bank of Rhizobium meliloti. Proc. Natl. Acad. Sci. USA 77: 7343-7351.

Fillingham, A. J., Wood, J., Bevan, J. R., Crute, I. R., Mansfield, J. W., Talor, J. D., and Vivian, A. 1992. Avirulence genes from Pseudomonas syringae pathovars phaseolicola and pisi confer specificity toward both host and non-host species. Physiol. Mol. Plant Pathol. 40:1-15.

Gabriel, D. W. 1989. Genetics of plant parasites populations and hostparasites specificity. Pages 343-379 in: Plant Microbe Interactions Molecular and Genetic Perspective. Vol. 3. T. Kosuge and E. W. Nester, eds. McGraw-Hill, New York.

Gopalan, S., Bauer, D. W., Alfano, J. R., Loniello, A. O., He, S. Y., and Collmer, A. 1996. Expression of the Pseudomonas syringae avirulence protein AvrB in plant cells alleviates its dependence on the hypersensitive response and pathogenicity (Hrp) secretion system in eliciting genotype-specific hypersensitive cell death. Plant Cell 8: 1095-1105.

Keen, N. T. 1990. Gene-for-gene complementarity in plant pathogen interactions. Annu. Rev. Genet. 24:447-463.

Kobayashi, D. Y., Tamaki, S. J., and Keen, N. T. 1989. Cloned avirulence genes from the tomato pathogen Pseudomonas pv. tomato confer cultivar specificity on soybean. Proc. Natl. Acad. Sci. USA 86:157-161.

Leach, J. E., and White, F. F. 1996. Bacterial avirulence genes. Annu. Rev. Phytopathol. 34:153-179.

Leister, R. T., Ausubel, F. M., and Katagiri, F. 1996. Molecular recognition of pathogen attack occurs inside of plant cells in plant disease resistance specified by the Arabidopsis genes RPS2 and RPM1. Proc. Natl. Acad. Sci. USA 93:15497-15502.

Lichter, A., Barash, I., Valinsky, L., and Manulis, S. 1995a. The genes involved in cytokinin biosynthesis in Erwinia herbicola pv. gypsophilae: Characterization and role in gall formation. J. Bacteriol. 177: 4457-4465.

Lichter, A., Manulis, S., Sagee, O., Gafni, Y., Gray, J., Meilan, R., Morris, R. O., and Barash, I. 1995b. Production of cytokinins by Erwinia herbicola pv. gypsophilae and isolation of a locus conferring cytokinin biosynthesis. Mol. Plant-Microbe Interact. 8:114-121.

Lichter, A., Manulis, S., Valinsky, L., Karniol, B., and Barash, I. 1996. IS1327, a new insertion-like element in the pathogenicity-associated plasmid of Erwinia herbicola pv. gypsophilae. Mol. Plant-Microbe Interact. 9:98-104.

Lindgren, P. B., Frederick, R., Govindarajan, A. G., Panopoulos, N. J.,
Staskawicz, B. J., and Lindow, S. E. 1989. An ice nucleation reporter gene system: Identification of inducible pathogenicity genes in Pseudomonas syringae pv. phaseolicola. EMBO J. 8:1291-1301.

Long, S. R. 1996. Rhizobium symbiosis: Nod factors in perspective. Plant Cell 8:1885-1898.

Long, S. R., and Staskawicz, B. J. 1993. Prokaryotic plant parasites. Cell 73:921-935.

Ma, Q.-S., Chang, M.-F., Tang, J.-L., Feng, J.-X., Fan, M.-J., Han, B., and Liu, T. 1988. Identification of DNA sequences involved in host specificity in the pathogenesis of Pseudomonas solanacearum strain T2005. Mol. Plant-Microbe Interact. 1:169-174.

Manulis, S., Gafni, Y., Clark, E., Zutra, D., Ophir, Y., and Barash, I. 1991a. Identification of a plasmid DNA probe for detection of strains of Erwinia herbicola pathogenic on Gypsophila paniculata. Phytopathology 81:54-57.

Manulis, S., Haviv-Chesner, A., Brandl, M. T., Lindow, S. E. and Barash, I. 1998. Differential involvement of indole-3-acetic acid biosynthetic pathways in pathogenicity and epiphytic fitness of Erwinia herbicola pv. gypsophilae. Mol. Plant-Microbe Interact. 11:634-642.

Manulis, S., Valinsky, L., Gafni, Y., and Hershenhorn, J. 1991b. Indole3-acetic acid biosynthetic pathways in Erwinia herbicola in relation to pathogenicity on Gypsophila paniculata. Physiol. Mol. Plant Pathol. 39:161-171.

Manulis, S., Valinsky, L., Nitzan, R., Mor, H., Ezra, D., and Barash, I. 1997. Genetic determinants for pathogenicity and specificity in the gall-forming bacterium Erwinia herbicola pv. gypsophilae. Proc. Congr. Mediterr. Phytopathol. Union, 10th. pp. 399-402.

Nizan, R., Barash, I., Valinsky, L., Lichter, A., and Manulis, S. 1997. The presence of $h r p$ genes on the pathogenicity-associated plasmid of the tumorigenic bacterium Erwinia herbicola pv. gypsophilae. Mol. Plant-Microbe Interact. 10:677-682.

Salch, Y. P., and Shaw, P. D. 1988. Isolation and characterization of pathogenicity genes of Pseudomonas syringae pv. tabaci. J. Bacteriol. 170:2584-2591.

Salmond, G. F. C., and Reeves, J. 1993. Membrane traffic wardens and protein secretion in Gram-negative bacteria. Trends Biochem. Sci. 18:7-12.

Sambrook, J., Fritsch, E. F., and Maniatis, T. A. 1989. Molecular Cloning: A Laboratory Manual. 2nd ed. Cold Spring Harbor Laboratory, Cold Spring Harbor, NY.

Starr, M. P. 1981. The genus Erwinia. Pages 1260-1271 in: The Prokaryotes. M. P. Starr, H. G. Truper, A. Baluws, and H. G. Schlegel, eds. Springer-Verlag, Berlin.

Staskawicz, B., Dahlbeck, D., Keen, N., and Napoli, C. 1987. Molecular characterization of cloned avirulence genes from race 0 and race 1 of Pseudomonas syringae pv. glycinea. J. Bacteriol. 169:5789-5794.

Swarup, S., Yang, Y., Kingsley, M. T., and Gabriel, D. W. 1992. A Xanthomonas citri pathogenicity gene, pthA, pleiotropically encodes gratuitous avirulence on nonhosts. Mol. Plant-Microbe Interact. 5:204-213.

Van den Ackerveken, G. F., Marois, E., and Bonas, U. 1996. Recognition of the bacterial avirulence protein AvrBs3 occurs inside the host plant cell. Cell 87:1307-1316.

Volcani, Z. 1985. Bacterial Diseases of Plants in Israel. Agricultural Research Organization, The Volcani Center, Bet Dagan, Israel.

Waney, V. R., Kingsley, M. T., and Gabriel, D. W. 1991. Xanthomonas campestris pv. translucens genes determining host-specific virulence and general virulence on cereals identified by Tn5-gusA insertion mutagenesis. Mol. Plant-Microbe Interact. 4:623-627.

Wei, Z. B., and Beer, S. V. 1995. hrpL activates Erwinia amylovora hrp gene transcription and is a member of the ECF subfamily of sigma factors. J. Bacteriol. 177:6201-6210.

Whalen, M. C., Innes, R., Bent, A., and Staskawicz, B. J. 1991. Identification of Pseudomonas syringae pathogens of Arabidopsis thaliana and a bacterial gene determining avirulence on both Arabidopsis and soybean. Plant Cell 3:49-59.

Whalen, M. C., Stall, R. E., and Staskawicz, B. J. 1988. Characterization of a gene from a tomato pathogen determining hypersensitive resistance in non-host species and genetic analysis of this resistance in bean. Proc. Natl. Acad. Sci. USA 85:6743-6747.

Xiao, Y., Heu, S., Jinseong, Y., Lu, Y., and Hutcheson, S. W. 1994. Identification of a putative alternate sigma factor and characterization of a multicomponent regulatory cascade controlling the expression of $P$. syringae pv. syringae Pss61 hrp and hrmA genes. J. Bacteriol. 176: 1025-1036. 